Int. J. Dev. Biol. 55: 841-849

doi: $10.1387 / \mathrm{ijdb} .113362 \mathrm{aa}$

\title{
Role of cancer-associated fibroblasts in breast cancer development and prognosis
}

\author{
ABDELILAH ABOUSSEKHRA* \\ King Faisal Specialist Hospital and Research Center, BMR, MBC \# 03-66, Riyadh, Kingdom of Saudi Arabia
}

\begin{abstract}
Since Paget's "Seed and Soil" hypothesis in 1889 on cancer growth and metastasis, several studies on various solid tumors have confirmed the active role of the tumor milieu on the onset, growth and spread of neoplastic cells. Fibroblasts constitute the major components of the tumor microenvironment (stroma), and are therefore the most studied cell type. Therefore, a large amount of data has emerged showing the cancer-promoting function of these cells through paracrine effects that escort tumor cells through all the carcinogenesis steps. This involves many signaling proteins that transmit the message in both directions, allowing cooperative crosstalk between cancer cells and their stroma. This prompted several researchers to investigate the potential use of the molecular and cellular features of active stromal fibroblasts to generate specific tools for prevention, prognosis and treatment of cancer. Herein, I review the cellular and molecular features of active cancer-associated fibroblasts and their origin. Additionally, I summarize our current understanding of the procarcinogenic actions of these cells and their potential prognostic value for breast cancer patients.
\end{abstract}

KEY WORDS: Cancer-associated fibroblasts, breast cancer, paracrine signaling, prognosis

\section{Introduction}

Breast cancer is the most frequent malignancy and the leading cause of cancer death among females, accounting for $23 \%$ of the total cancer cases and $14 \%$ of the cancer deaths worldwide in 2008 (Jemal et al.). Breast carcinomas are complex tumors that result mainly from the accumulation of genetic and epigenetic alterations in epithelial cells of the mammary gland. However, carcinoma cells, like normal epithelial cells, live in a complex microenvironment that includes the extracellular matrix (ECM) as well as cellular components such as immune and inflammatory cells, endothelial cells, adipocytes, fibroblasts and bone marrow-derived cells (Arendt et al., 2009). Stromal-epithelial interactions have a fundamental role in normal mammary development such as determining normal duct formation and the initiation and maintenance of oestrogen and/or progesteron responsiveness in mammary epithelial cells (Kim et al., 2005). Furthermore, normal stroma controls epithelial cell polarity, loss of which leads to an increase in cell proliferation and tumorigenesis (Polyak and Kalluri, 2010). Fibroblasts, the predominant cells of the stroma, are responsible for the elaboration of most of the components of connective tissue (Sappino et al., 1990). Mammary gland fibroblasts produce ECM molecules such as fibronectin and tenascin, which influence cell adhesion and proliferation (Schor and Schor, 2001). Thereby, modifications in stromal fibroblasts can play a significant role in overall cancer development. Indeed, several recent publications have reported genetic and epigenetic changes in stromal fibroblasts that modulate the expression of many genes encoding growth factors and cytokines (Hu and Polyak, 2008; Lin et al., 2009). These soluble factors affect the microenvironment, fertilize the soil and favor the growth of the seed (tumor). To progress and spread, tumor cells keep interacting with their stromal fibroblasts through secreted molecules. This reciprocal heterotypic signaling plays a major role in the various steps of tumorigenesis. However, a key question remains: which comes first, the dysfunction of epithelial cells or the dysfunction of their microenvironment? There is so far no answer to this chicken-and-egg conundrum, but it is now becoming evident that each compartment is affecting the other one with one ultimate objective: growth and expansion of neoplastic cells. Therefore, understanding the meaning of the crosstalk between neoplastic cells and their stromal fibroblasts, one of the important hallmarks

Abbreviations used in this paper: CAF, cancer-associated fibroblast; $\mathrm{CAV}$, caveolin; ECM, extracellular matrix; HGF, heaptocyte growth factor; MMP, matrix metalloprotein; PTEN, phosphatase and TENsin homolog; VEGF, vascular endothelial growth factor.

\footnotetext{
*Address correspondence to: Abdelilah Aboussekhra. King Faisal Specialist Hospital and Research Center, BMR, MBC \# 03-66, PO Box 3354, Riyadh 11211, Kingdom of Saudi Arabia (KSA). Fax: +966-1-442-7858.Tel: +966-1-464-7272 ext 32840. e-mail: aboussekhra@kfshrc.edu.sa
} 
of cancer (Pietras and Ostman, 2010), has became fundamental in improving the prognosis and therapy of various solid tumors, including mammary carcinomas.

\section{Cancer-associated fibroblasts}

Fibroblasts are non-vascular, non-epithelial and non-inflammatory cells that form the basic cellular component of connective tissue and contribute to its structural integrity (Tarin, 1969). They play important roles in wound healing, regulation of epithelial differentiation and inflammation (Tomasek et al., 2002). In healthy organs, fibroblasts have a low proliferation index and minimum metabolic capacity. By contrast, during wound healing and in cancers, fibroblasts become activated, start to proliferate, secrete higher amounts of ECM components, and acquire contractile features (Polyak and Kalluri, 2010). In tumors, these fibroblasts are known as reactive fibroblasts, peri-tumoral fibroblasts, myofibroblasts, tumor-associated or cancer-associated fibroblasts (CAFs). These cells present plump spindle-shaped mesenchymal structure with indented nuclei, peripheral myofilaments and fibronexus junctions (De Wever et al., 2008). Myofibroblast cells were first identified by Gabbiani et al., during wound healing (Gabbiani et al., 1971) and were defined by Kalluri and Zeisberg as "activated fibroblasts within desmoplastic lesions that are associated with malignant tumors and often express $\alpha$-smooth-muscle actin ( $\alpha$-SMA)" (Kalluri and Zeisberg, 2006). These cells are also positive for vimentin and desmin, but do not express cytokeratin, CD31 and smooth muscle myosin. These markers are often used to distinguish between myofibroblasts and normal fibroblast, epithelial, endothelial or smooth muscle cells (Beacham and Cukierman, 2005). While most CAFs are active fibroblasts, a small proportion remains inactive. Indeed, in breast tumors $80 \%$ of fibroblasts are in active form (Sappino et al., 1988). Active fibroblasts play similar roles in wound healing and in cancer, which is considered as a wound that does not heal (Dvorak, 1986). However, while in normal wounds active fibroblasts are transients, CAFs are persistent in tumors. Active fibroblasts secrete high levels of various growth factors, cytokines, chemokines, and ECM degrading proteases such as the MMPs (Bhowmick et al., 2004). These factors are used by activated fibroblasts to communicate with cancer cells as well as with other stromal cells. Microarray and proteomics analysis have revealed distinct mRNAand protein expression profiles in CAFs as compared to their adjacent normal counterparts (NFs) and normal fibroblasts isolated from mammary reduction surgery (NBFs), showing genetic and/or epigenetic alterations in these stromal fibroblasts (Allinen et al., 2004; Bauer et al., 2010; Hawsawi et al., 2008; Sadlonova et al., 2009). Consistent with this, CAFs exhibit some cancer-specific changes, including defective p53/p21-dependent signaling pathway in response to $\gamma$-rays, high level of survivin, increased resistance to cisplatin and UV light and strong expression of the proliferation markers Ki-67 and PCNA (Hawsawi et al., 2008). However, these cells are non-neoplastic because they senesce in culture and do not grow in vivo in tumor xenografts (Kojima et al., 2010).

\section{Origin of mammary cancer-associated fibroblasts}

In light of recent findings, breast carcinoma-associated fibroblasts are believed to have 3 major distinct origins, not necessary exclusive. The first one is the transformation within the tumor of stromal resting fibroblasts into myofibroblasts. Three dimensional coculture experiments have shown that fibroblasts readily converted into a graded pattern of myogenic differentiation when confronted with tumor cells, with strong effect on cells that were in the immediate vicinity of tumor cells (Ronnov-Jessen et al., 1995). Recently, conversion of resident fibroblasts into myofibroblasts during the course of tumor progression was also observed in a coimplantation breast tumor xenograft model (Kojima et al., 2010). These results indicate the possible transformation of breast stromal fibroblasts to myofibroblasts under cancer-related paracrine effects. In fact, TGF- $\beta$ can induce the production of $\alpha$-SMA in mammary fibroblasts in vitro and consequently transdifferentiates fibroblasts into CAFs (Vaughan et al., 2000) (Fig. 1).

The second possible origin of breast myofibroblasts are specialized circulating progenitor cells such as fibrocytes and bone marrow-derived mesenchymal stem cells (MSCs). Fibrocyte cells are known to express hematopoetic stem cell markers, monocyte lineage and fibroblast markers. Fibrocytes have been identified in breast carcinomas and these cells can differentiate into CAFs (Barth et al., 2002; Mori et al., 2005). MSCs are known to migrate to and engraft at tumor sites (El-Haibi and Karnoub, 2010; Spaeth et al., 2009). MSCs can also differentiate into active fibroblasts expressing $\alpha \_S M A$ and exhibiting myofibroblast features (Mishra et al., 2008; Spaeth et al., 2009). In fact, addition of lysophosphatidic acid (LPA) induces the expression of $\alpha$-SMA and SDF-1 in MSCs, which stimulates the differentiation of MCSs to myofibroblast-like cells (Jeon et al., 2008). Like myofibroblasts, activated MSCs by prolonged exposure to conditioned media from cancer cells ex-

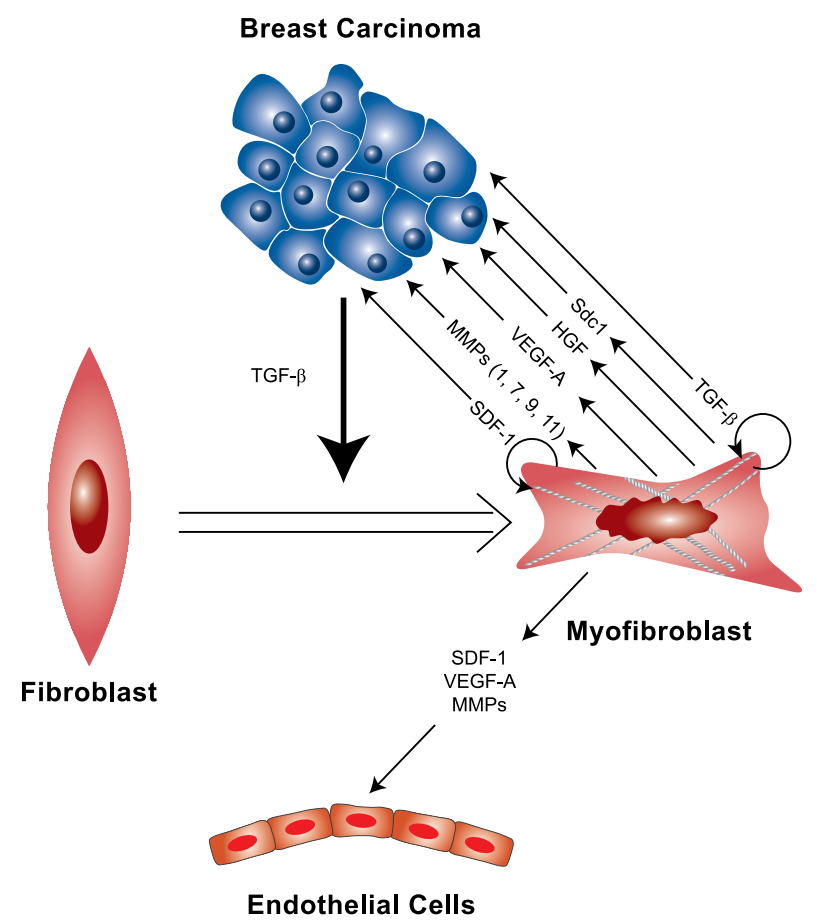

Fig. 1. Active fibroblasts promote cancer growth and angiogenesis through secreted factors. Breast carcinomas can activate stromal fibroblasts through secretion of TGF- $\beta$. Consequently, activated fibroblasts enhance tumor growth and angiogenesis via secreted mediators. SDF-1 and TGF- $\beta$ cytokines maintain the active state of stromal fibroblast through autocrine signaling loops. 
pressed high levels of SDF-1, a hallmark of tumor myofibroblasts, and enhanced tumor growth (Mishra et al., 2008). These findings strongly suggest that MSCs constitute a major source of cancerassociated activated fibroblasts in breast tumors.

The third source of CAFs comes from the trans-differentiation of different cell types present in the breast such as epithelial, endothelial, adipocyte and pericyte cells into myofibroblasts. The epithelial to mesenchymal transition (EMT), an important step during cancer progression, has been shown to produce myofibroblast cells, with enhanced migratory capacity, invasiveness and increased expression of ECM proteins (Kalluri and Zeisberg, 2006; Polyak and Weinberg, 2009). Likewise, endothelial to mesenchymal transition (EndMT), characterized by the loss of endothelial markers such as CD31, and the expression of $\alpha \_$SMA and other mesenchymal markers, also produced myofibroblast-like cells (Potenta et al., 2008; Zeisberg et al., 2007). Interestingly, both EMT and EndMTtransitions can take place upon exposure to TGF- $\beta$ (Kalluri and Weinberg, 2009; Massague, 2008). Furthermore, studies using transgenic mice have revealed that up to $40 \%$ of CAFs arise through EndMT (Zeisberg et al., 2007). Taken together, these findings suggest that breast cancer-associated fibroblasts could have different origins. However, the local cells seem to constitute the most prominent source, while other invader cells may constitute a minor pool. It is also possible that the origin of CAFs varies depending on the stage of carcinogenesis.

\section{Role of CAFs in breast cancer development and spread}

There is substantial evidence that CAFs actively contribute to the growth, expansion and dissemination of neoplastic epithelial cells. Thereby, Cheng and Weiner considered stromal fibroblasts as the "contracted farmers" that prepare a terrain for the tumor's ease and fertile growth (Cheng and Weiner, 2003). To confirm this at the cellular level, Shekhar and his collaborators used a three-dimensional cell-cell interaction model and have shown the importance of stromal fibroblasts in breast epithelial growth and differentiation in vitro (Shekhar et al., 2001). This effect was also revealed in vivo by showing that human breast cell line MCF-7 cells are hardly tumorigenic in SCID mice, their tumoriginity was dramatically increased when inoculated with fibroblasts (Trimis et al., 2008). Furthermore, the coinoculation of transformed fibroblasts with breast cancer cells accelerated the growth and shortened the latency period of human tumors in athymic mice (Camps et al., 1990). Loss of TGF- $\beta$ type II receptor in fibroblasts cotransplanted with mammary carcinoma cells into mammary fat pad promoted tumor growth, invasion and metastasis (Cheng et al., 2005). In other studies using tumor xenograft models, CAFs were shown to accelerate the growth rate of tumors and enhanced tumor angiogenesis through mobilization and recruitment of endothelial cells (Hu et al., 2009; Orimo et al., 2005). Together, these results provide clear evidence on the active role of myofibroblasts on various steps of breast carcinogenesis. This raises an important question on the nature of the mediators of this pro-tumorigenic factors and the mechanism of their regulation.

\section{CAF-derived breast cancer promoting factors}

During the development of mammary carcinomas the epithelial and stromal compartments coevolve, through heterotypic interactions that do not necessitate cell-cell contact but seems rather driven by secreted soluble effectors. Indeed, in breast cancer tissues, most of the gene expression changes that occur in the stroma take place in ductal carcinoma in situ (DCIS) and only few extra ones occur in the stroma of invasive tumors (Casey et al., 2009; Ma et al., 2009). This indicates that paracrine and endocrine effects are at the origin of these modifications since the basement membrane is largely intact in DCIS. Using a transwell system allowing diffusible factor exchange and microarray analysis, it has been shown that 160 and 178 genes were differentially expressed between MDA-MB231 and MCF-10 cells cocultured with CAFs as compared to monocultures, respectively (Rozenchan et al., 2009). Moreover, co-injection of lethally irradiated fibroblasts or inclusion of fibroblast-conditioned medium with breast cancer cell grafts increased carcinogenesis and tumor growth (Camps et al., 1990; Noel et al., 1993). These findings show that CAFs promote tumor growth by secreting soluble factors such as proangiogenic factors, matrix mettaloproteinases (MMPs), cytokines as well as chemokines and growth factors.

\section{SDF-1}

The knowledge that stromal cells have the ability to stimulate oncogenenesis has been taken a step further by showing that stromal fibroblasts present in invasive human breast carcinomas promote tumor growth and angiogenesis through elevated SDF-1 (CXCL12) secretion (Allinen et al., 2004; Orimo et al., 2005). These two reports have clearly shown the important role that the SDF-1 cytokine plays in the crosstalk between myofibroblast cells and tumor cells. Allinen et al., have also shown that myofibroblasts SDF-1 enhances the proliferation, migration and invasion of cancer cells (Allinen et al., 2004) (Fig. 1). This effect is mediated through preferential binding of SDF-1 to the CXCR-4 receptor in cancer cells, which induces different intracellular pathways related to several aspects of tumor progression (Teicher and Fricker, 2010). Furthermore, CAFs promoted the proliferation of breast cancer CD44+CD24-stem cells in mammosphere cells in an SDF-1-dependent manner, and enhanced their tumorigenicity in mice (Huang et al., 2010). SDF-1 also enhanced angiogenesis by recruiting endothelial progenitor cells into carcinomas (Orimo et al., 2005).

\section{VEGF-A (VEGF)}

The vascular endothelial growth factor $A(V E G F-A)$ is an important mediator of angiogenesis and also has a potent tumor angiogenic effect. VEGF expression in breast cancer cells can stimulate CXCR4, linking VEGF expression to the migratory potential of cells and to SDF-1 signaling (Bachelder et al., 2002). Beside angiogenesis, VEGF released by activated stroma increased the growth of ERpositive malignant epithelial cells and of adjacent normal epithelium (Pinto et al., 2010).

\section{HGF}

Another important myofibroblast mediator is the Hepatocyte Growth Factor (HGF) protein, which is primarily expressed and secreted from fibroblasts and can promote cancer development and progression (Matsumoto and Nakamura, 2006). It has been recently shown that breast cancer cells induce CAFs to secrete HGF, which in turn enhances breast tumorigenesis (Tyan et al., 2011).

\section{$T G F-\beta$}

Kojima and cowokers have recently shown that autocrine TGF$\beta$ signaling drives the evolution of tumor-promoting mammary 
stromal myofibroblasts (Kojima et al., 2010). Furthermore, ectopic expression of HGF and/or TGF- $\beta$ in mouse fibroblasts before the implantation of ostensibly normal human mammary epithelial cells resulted in the outgrowth of benign and malignant lesions in the humanized fat pads of NOD/SCID mice (Kuperwasser et al., 2004; Wu et al., 2009). This suggests an important role of stromal fibroblast TGF- $\beta$ in promoting breast carcinogenesis (Fig. 1).

\section{MMPs}

The other major intermediate in the intercommunication between tumors and their stromal fibroblasts are Matrix metalloproteinases (MMPs). These prominent proteases that play crucial roles in various physiological processes including development, inflammation and ECM degradation, are abundantly and some time exclusively secreted by stromal cells, and play key roles in the modulation of the tumor microenvironment. They also regulate various signaling pathways that control tumor growth, angiogenesis and metastasis (Kessenbrock et al., 2010). It has been shown that breast cancer cells induce stromal fibroblasts to express MMP9 via secretion of TNF- $\alpha$ and TGF- $\beta$, and that the level of induction depends on the degree of malignancy of cancer cells (Stuelten etal., 2005). Furthermore, elevated levels of MMP9 were found associated with tumors and correlate with cancer invasion and metastasis (Nabeshima et al., 2002). In addition, fibroblasts were shown to promote breast cancer cell invasion by upregulating MMP9 production (Wang et al., 2002). Recently, Hu et al., have shown that fibroblast MMP9 promotes breast cancer cells invasion in a coculture in vitro model (Hu et al., 2009). This indicates that MMP9 plays an important role in the cross-talk between breast tumors and their milieu. Furthermore, MMP1 and MMP7 are mainly fibroblastic and can increase the susceptibility to breast cancer when overexpressed in transgenic mice (Lynch and Matrisian, 2002). MMP11 was identified and cloned as a gene expressed specifically in stromal cells surrounding invasive breast carcinomas (Basset et al., 1990). While fibroblasts expressing normal MMP11 support in vivo growth of breast cancer cells, MMP11-null fibroblasts do not promote such growth, showing an important role of this protease in fibroblastpromoting breast cancer growth (Masson et al., 1998) (Fig. 1).

\section{SDC1}

Proteoglycans also modulate the reciprocal interactions between tumor and stromal cells through binding to ECM constituents and important growth factors (Friedl, 2009). The syndecans compose an important family of transmembrane cell surface heparan sulfate proteoglycans (HSPGs), which regulate cell-cell and cell-ECM adhesion, cell migration, and growth factor activity (Bernfield et al., 1999). Among syndecan family members, Sdc1 is expressed mainly in normal epithelial cells and its induction in stromal fibroblasts is observed in more than $70 \%$ of human breast tumors. Breast carcinoma cells induce Sdc1 in fibroblasts, which reciprocally promote cancer cell growth (Maeda et al., 2006; Su et al., 2007). The soluble Sdc1 extracellular domain stimulates carcinoma cell growth in concert with fibroblast growth factor 2 (FGF2) and SDF-1, possibly through shuttling them from CAFs to carcinoma cells (Su et al., 2007).

Altogether, these findings indicate that carcinoma-stroma crosstalk is ensured by a myriad of mediators that enable the growth and progression of tumor cells. Several other potential mediators are still awaiting identification and characterization to fully understand this complex cellular cross-signaling and decipher its meaning.

\section{Genetic and epigenetic changes in breast cancer- associated myofibroblasts}

Several studies have reported important changes in gene expression in CAFs as compared to NFs and NBFs. Using serial analysis of gene expression, Allinen and coworkers have shown extensive gene expression changes in all cell types during cancer progression, and that a significant fraction of altered genes encode secreted proteins and receptors. In a recent study, Bauer et al., used Affymetrix Human Genome U133 Plus 2.0 arrays to examine differential gene expression between CAFs and NFs from the same patients. They have identified 21 genes up-regulated and 10 genes down-regulated in CAFs, as compared with NFs. These genes are implicated in paracrine or intracellular signaling, transcriptional regulation, ECM production and cell adhesion/migration (Bauer et al., 2010). In another study, 420 genes were found to be differentially expressed in CAFs versus NBFs (Sadlonova et al., 2009). Furthermore, 2-Dimentional(2D) gelelectrophoresis analysis revealed a great variation in global protein expression between CAFs, NFs and NBFs. Intriguingly, even fibroblasts adjacent to a tumor in a histologically normal part of the breast presented variations in protein expression as compared to NBFs (Hawsawi et al., 2008). These findings clearly indicate that stromal fibroblasts both into breast tumors and in their "normal" surrounding areas are subject to variation in the expression of various genes directly or indirectly implicated in functional crosstalk between the tumor and its microenvironment.

Since many of these changes are maintained after prolonged cell culture even in absence of cancer cells, it is plausible that they result from genetic and/or epigenetic alterations. Indeed, several studies have shown alteration in DNA methylation pattern in breast CAFs. Using methylation-specific digital karyotyping, Hu et al., have shown global alteration in DNA methylation pattern in both tumor epithelial cells as well as in breast cancer stromal fibroblasts as compared to their normal counterparts ( $\mathrm{Hu}$ et al., 2005). Furthermore, Friegl and cowokers have found differential methylation status in five selected genes between normal and breast cancer-associated stroma. This methylation was HER-2/ neu-dependent (Fiegl et al., 2006). Together, these data indicate that breast cancer stromal fibroblasts are epigenetically abnormal, which could explain the stable gene expression variation observed in CAFs even after serial passaging in vitro.

On the other hand, the presence of somatic genetic alterations in active fibroblasts remains controversial (Campbell et al., 2009; Eng et al., 2009). While several groups reported the presence of mutations only in cancer epithelial cells, chromosomal loss of heterozygosity ( $\mathrm{LOH}$ ) and mutations have also been reported in CAFs by other groups (Campbell et al., 2011; Eng et al., 2009). Indeed, up to $87.5 \% \mathrm{LOH}$ were found in CAFs microdissected from formalin-fixed paraffin-embedded breast ductal carcinoma in situ (DCIS) samples (Moinfar et al., 2000). Another group has independently confirmed these results and has shown the presence of frequent genetic alterations in invasive human breast cancers (loss of heterozygosity and TP53 mutations) occurring not only in the neoplastic epithelial cells, but also in the adjacent fibroblastic stroma, and that both components can share clonal features (Wernert et al., 2001). Other studies have also identified 
$\mathrm{LOH}$ in CAFs and have shown significant association between the LOH signature in stromal fibroblasts and breast tumor grade and lymph node metastasis (Fukino et al., 2007; Weber et al., 2006). Looking for loss of heterozygosity in the two tumor suppressor TP53 and PTEN genes in epithelial and stromal tumors, Kurose and colleagues have found mutations in both compartments. However, in most cases PTEN and TP53 mutations did not occur together in the same tissue compartment. Their exclusive nature and the presence of discordant mutations even within the same gene suggested that genetic alterations occur independently in the stroma and the epithelium (Kurose et al., 2002). What are the reasons of this discrepancy? Several explanations have been proposed and were the topic of recent reviews (Campbell et al., 2009; Eng et al., 2009).

Are these genetic/epigenetic alterations the cause or the consequence of the presence of cancer cells? It has become clear that cancer cells modulate their ecosystem through paracrine signaling in order to grow and invade. However, it remains unclear whether alteration of the microenvironment is a prerequisite for tumor onset. In fact, there are indications that stromal alteration(s) precede the malignant conversion of tumor cells (Moinfar et al., 2000). For instance, epigenetic modifications in stroma were shown to be unique and discrete from their associated cancer cells ( $\mathrm{Hu}$ et al., 2005; Kurose et al., 2002). In addition, active fibroblasts can trigger genetic/epigenetic alterations in the epithelial cells. CAFs from breast cancer were able to trigger AKT1-mediated epigenetic silencing of the tumor suppressor cystatin $\mathrm{M}$ (CST6) and other genes in epithelial cells (Lin et al., 2008). Epigenetic silencing of CST6 has been observed in breast cancer cell lines and in metastatic lesions (Ai et al., 2006; Rivenbark et al., 2007). These pro-tumoral stromal modifications could be acquired or inherited. It is well known that there is a genetic component in the predisposition to breast

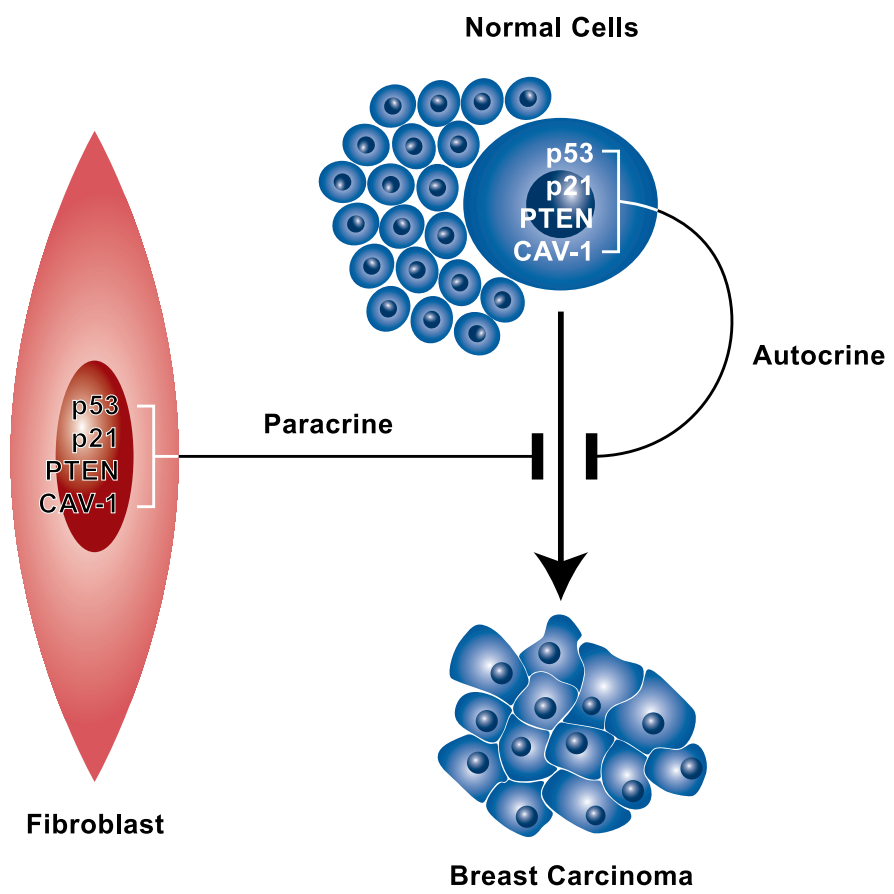

Fig. 2. Autocrine and paracrine tumor suppressor functions of p53,p21, PTEN and caveolin1 (CAV-1). These tumor suppressor proteins repress breast carcinogenesis from epithelial cells and also from stromal fibroblasts. cancer. Indeed, skin fibroblasts derived from breast cancer patients may also be altered and exhibit characteristics associated with a transformed phenotype (Azzarone et al., 1984). In another study, skin fibroblast cells derived from breast cancer patients exhibited higher sensitivity to irradiation than skin fibroblastic cells from healthy women (Hannan et al., 2001). In addition, Schor and colleagues reported that skin fibroblasts obtained from cancer patients display foetal-like migratory behavior on collagen gels (Schor et al., 1985). They also described a tumor-like phenotype of fibroblasts isolated from the healthy relatives of patients with familial breast disease (Haggie et al., 1987). This shows that not only cells that are in proximity of the tumor are genetically altered, but also cells of the whole body. This could explain the predisposition to cancer development, and the possible inheritance of alterations, essentially epigenetic, in fibroblast cells.

\section{Role of tumor suppressor genes in regulating epithelial- fibroblast cross signaling}

Mesenchymal-epithelial cell interactions and their role in tumor growth and development are now well recognized. However, the genes and pathways controlling these tumor-promoting effects are not fully delineated. Several lines of evidence indicate the implication of tumor suppressor genes in controlling the pro-carcinogenic effects of stromal fibroblasts in a paracrine manner (Fig. 2).

\section{TP53}

The versatile p53 tumor suppressor protein was the first shown to play this role. Komarova et al., have demonstrated p53-mediated growth inhibition of cancer cells in vitro through paracrine effect (Komarova et al., 1998). Furthermore, in mice xenograft models, p53-deficient fibroblasts significantly increased the tumorigenicity of the human MCF-7 breast cancer cell line more than p53 normal counterparts (Kiaris et al., 2005). In another study, p53 induction affected the secreted level of several factors implicated in the mesenchymal-epithelial crosstalk (Khwaja et al., 2006). To elucidate the p53-dependent signaling pathways and mediators, Moskovits et al., have shown that stromal fibroblast p53 attenuates cancer cell migration and invasion through repression of SDF-1 expression/secretion (Moskovits et al., 2006). These results show cell non-autonomous tumor suppressor action of p53 in breast carcinogenesis (Bar et al., 2009).

\section{CDKN1A}

One of the most important targets of p53 is the cyclin-dependent kinase inhibitor p21. p21 deficiency in stromal fibroblasts also accelerated tumor growth in vivo through cell non-autonomous mechanism. Indeed, transient siRNA-mediated p21 suppression in fibroblasts stimulated breast cancer growth in vivo (Trimis et al., 2008). This suggests that the paracrine anti-tumor effect of p53 could be mediated through $\mathrm{p} 21$, and that this pathway may play a capital role in controlling the epithelia-stroma crosstalk (Fig. 2). The observation that p53 and p21 protein levels are down-regulated in $83 \%$ CAFs as compared to NFs, supports a major nonautonomous tumor suppressor function of these two important tumor suppressor proteins (Hawsawi et al., 2008).

\section{PTEN}

PTEN, another important tumor suppressor gene, with lipid and 
protein phosphatase activity, has been found mutated in various types of cancer, including breast carcinomas (Cully et al., 2006). The role of PTEN in stroma has been recently revealed in an experimental mouse model by showing that inactivation of PTEN in stromal fibroblasts of mouse mammary glands accelerated the initiation, progression and malignant transformation of mammary tumors, through increase in chemokine and cytokine production in the tumor microenvironment. The authors have identified the Pten-Ets2 axis as a critical stroma-specific signaling pathway that suppresses mammary epithelial tumors (Trimboli et al., 2009).

\section{CAV-1}

Caveolin-1 (CAV-1) codes for a principal component of caveolae membranes, and is expressed in various human cell types, including fibroblasts and mammary epithelial cells (Engelman et al., 1998; Lee et al., 1998). It has been reported that $C A V$-1-deficient mammary stromal fibroblasts share several features with human CAFs, including increased levels of secreted proliferative and angiogenic growth factors (Sotgia et al., 2009). Moreover, co-injection of caveolin-1 deficient human fibroblasts with MDA-MB-231 cells, increased both tumor mass and tumor volume by 4-fold, showing the paracrine tumor promoting effect of this gene (Trimmer et al.). Several lines of evidence indicate that CAV-1 also acts as tumor suppressor gene in breast cancer (Bouras et al., 2004). Furthermore, Williams et al., have shown that the combined loss of the tumor suppressor INK4a and caveolin-1 synergistically enhances cell proliferation and oncogene-induced tumorigenesis (Williams et al., 2004).

Together, these results indicate that several tumor suppressor genes act both in autocrine and paracrine fashion to stop tumor growth and spread. It is thereby possible that other important tumor suppressor genes have also this dual function (Fig. 2).

\section{CAFs as marker of patient prognosis}

The functional interplay existing between epithelial cells and their microenvironment supposes that CAFs can constitute a valuable prognostic and predictive marker for breast cancer patients. Indeed, numerous studies have shown correlation between gene expression in breast myofibroblasts and patients outcome. Finak et al., have identified a new stroma-related 26-gene expression signature with strong association with breast cancer patient outcome (Finak et al., 2008). In another study, a newly identified stromaderived signature predicted resistance of breast cancer patients to neoadjuvant chemotherapy with 5-fluorouracil, epirubicin and cyclophosphamide (Farmer et al., 2009). Since fibroblasts are the major cell type of breast stromal compartment, it is possible that these stroma-dependent predictive values are stromal fibroblastrelated. Furthermore, the status of the tumor suppressor p53 protein in stromal fibroblasts may also be a good predictive marker for invasive breast carcinomas. Hasebe and coworkers have shown that p53 expression in tumor stromal fibroblasts, but not in tumor cells, is an independent factor associated with the number of nodal metastases and the outcome of invasive ductal carcinoma patients (Hasebe et al., 2010). Additionally, the same group has recently shown a close association between p53 protein expression in tumor-stromal fibroblasts, especially in surgical specimens, and both the presence of nodal metastasis and the outcome of IDC patients who received neoadjuvant therapy (Hasebe et al., 2010).
Another potentially good predictive stromal marker is the CAV-1 gene. Indeed, caveolin-1-/- mammary stromal fibroblasts gene signature is predictive of poor clinical outcome in breast cancer patients treated with tamoxifen (Sotgia et al., 2009). These findings were validated in two independent patient populations, confirming that stromal Cav-1 expression in human breast cancers is a powerful single independent predictor of early disease recurrence, metastasis, and poor clinical outcome (Sloan et al., 2009; Witkiewicz et al., 2009). Witkiewicz et al., suggested the use of stromal Cav-1 to stratify breast cancer patients to high-risk (absence of Cav-1) and low-risk groups (Witkiewicz et al., 2009). The observation that p53-deficient cells showed no Cav-1 expression suggests an association between p53 status and Cav-1 expression, (Lee et al., 1998). This indicates that the loss of these two important tumor suppressor proteins in stromal fibroblasts could be of great predictive value for breast as well as other types of cancer. Moreover, high stromal fibroblast platelet-derived growth factor (PDGF) beta-receptor expression was significantly associated with high histopathological grade, estrogen receptor negativity, high HER2 expression, significantly shorter recurrence-free and breast cancerspecific survival. The prognostic significance of stromal PDGF beta-receptor expression was particularly prominent in tumors from premenopausal women (Paulsson et al., 2009). Similarly, stromal CD10 expression in invasive breast carcinoma was shown to be associated with ER negativity, higher tumor grade and decreased survival, and constitutes another potential important prognostic marker (Makretsov et al., 2007). In addition, multivariate analysis showed that SDF-1 status was also an independent factor related to overall survival in patients with ER-positive tumors, and therefore stromal SDF-1 status could have a significant prognostic value and may be clinically useful for assigning adjuvant therapy to patients with ER-positive invasive breast cancers (Kobayashi et al., 2009). Recently Yamashima and colleagues showed that the expression of the other important hallmark of myofibroblasts, $\alpha$-SMA, correlates with invasive growth and poor clinical prognosis (Yamashita et al., 2010). Likewise, patients with stroma rich-tumors had a shorter relapse-free period and overall survival compared to stroma-poor tumors (de Kruijf et al., 2011). These findings corroborate the previously shown association between the presence of large number of CAFs and high grade as well as poor prognosis (Cardone et al., 1997). These and other findings provide clear evidence that, in the near future, stromal fibroblasts will be of great value for the diagnostic and prognostic of breast tumors and will also help for the development of individualized treatments that will take into account the status and effects of tumor microenvironment.

\section{Conclusion}

During breast carcinogenesis, activated stromal fibroblasts have active role in the initiation, progression, metastasis and recurrence of tumors, which adds new levels of complexity to cancer biology, but also brings new prognostic and therapeutic opportunities. Indeed, current cancer treatments target primarily carcinoma cells (seed), while they should also try to normalize the stroma (soil) and inhibit its supportive role. Therefore, a deep understanding of the epithelial-stromal biochemical interactions and molecular reciprocal heterotypic signaling is mandatory for preventive strategies and for the development of new therapeutic regimens that take into consideration the pro-carcinogenic actions of the microenvironment. 
The fact that tumor-associated fibroblasts present some tumor features and are genetically stable and also different from normal fibroblasts make them important potential targets of anti-cancer therapy. Alexander Fleming said "If the soil causes the disease, the cure to the disease also lies in it".

\section{Acknowledgements}

I'm grateful to Velasco Melvin for his great help in preparing the figures, and Dr. Coralie Poizat, Dr. Taher Al-Tweigeri and Dr. Hazem Ghebah for the critical reading of the manuscript, and their valuable comments. I'm also very thankful to King Abdulaziz City for Science and Technology (KACST) for their valuable help. This work was in part supported by a KACST grant \# AT-24-32/RAC\#2031091.

\section{References}

AI, L., KIM, W.J., KIM, T.Y., FIELDS, C.R., MASSOLL, N.A., ROBERTSON, K.D., and BROWN, K.D. (2006). Epigenetic silencing of the tumor suppressor cystatin M occurs during breast cancer progression. Cancer Res 66: 7899-7909.

ALLINEN, M., BEROUKHIM, R., CAI, L., BRENNAN, C., LAHTI-DOMENICI, J., HUANG, H., PORTER, D., HU, M., CHIN, L., RICHARDSON, A., et al., (2004). Molecular characterization of the tumor microenvironment in breast cancer. Cancer Cell 6: 17-32.

ARENDT, L.M., RUDNICK, J.A., KELLER, P.J., and KUPERWASSER, C. (2009). Stroma in breast development and disease. Semin Cell Dev Biol 21: 11-18.

AZZARONE, B., MAREEL, M., BILLARD, C., SCEMAMA, P., CHAPONNIER, C., and MACIEIRA-COELHO, A. (1984). Abnormal properties of skin fibroblasts from patients with breast cancer. Int J Cancer 33: 759-764.

BACHELDER, R.E., WENDT, M.A., and MERCURIO, A.M. (2002). Vascular endothelial growth factor promotes breast carcinoma invasion in an autocrine manner by regulating the chemokine receptor CXCR4. Cancer Res 62: 7203-7206.

BAR, J., MOSKOVITS, N., and OREN, M. (2009). Involvement of stromal p53 in tumor-stroma interactions. Semin Cell Dev Biol 21: 47-54.

BARTH, P.J., EBRAHIMSADE, S., RAMASWAMY, A., and MOLL, R. (2002). CD34+ fibrocytes in invasive ductal carcinoma, ductal carcinoma in situ, and benign breast lesions. Virchows Arch 440: 298-303.

BASSET, P., BELLOCQ, J.P., WOLF, C., STOLL, I., HUTIN, P., LIMACHER, J.M., PODHAJCER, O.L., CHENARD, M.P., RIO, M.C., and CHAMBON, P. (1990). A novel metalloproteinase gene specifically expressed in stromal cells of breast carcinomas. Nature 348: 699-704.

BAUER, M., SU, G., CASPER, C., HE, R., REHRAUER, W., and FRIEDL, A. (2010). Heterogeneity of gene expression in stromal fibroblasts of human breast carcinomas and normal breast. Oncogene 29: 1732-1740.

BEACHAM, D.A., and CUKIERMAN, E. (2005). Stromagenesis: the changing face of fibroblastic microenvironments during tumor progression. Semin Cancer Biol 15: 329-341.

BERNFIELD, M., GOTTE, M., PARK, P.W., REIZES, O., FITZGERALD, M.L., LINCECUM, J., and ZAKO, M. (1999). Functions of cell surface heparan sulfate proteoglycans. Annu Rev Biochem 68: 729-777.

BHOWMICK, N.A., NEILSON, E.G., and MOSES, H.L. (2004). Stromal fibroblasts in cancer initiation and progression. Nature 432: 332-337.

BOURAS, T., LISANTI, M.P., and PESTELL, R.G. (2004). Caveolin-1 in breast cancer. Cancer Biol Ther 3: 931-941.

CAMPBELL, I., POLYAK, K., and HAVIV, I. (2009). Clonal mutations in the cancerassociated fibroblasts: the case against genetic coevolution. Cancer Res 69: 6765-6768; discussion 6769.

CAMPBELL, I., QIU, W., and HAVIV, I. (2011). Genetic changes in tumour microenvironments. J Pathol 223: 450-458.

CAMPS, J.L., CHANG, S.M., HSU, T.C., FREEMAN, M.R., HONG, S.J., ZHAU, H.E., VON ESCHENBACH,A.C., and CHUNG, L.W. (1990). Fibroblast-mediated acceleration of human epithelial tumor growth in vivo. Proc NatIAcad Sci USA87: 75-79.

CARDONE, A., TOLINO, A., ZARCONE, R., BORRUTO CARACCIOLO, G., and TARTAGLIA, E. (1997). Prognostic value of desmoplastic reaction and lymphocytic infiltration in the management of breast cancer. Panminerva Med 39: 174-177.
CASEY, T., BOND, J., TIGHE, S., HUNTER, T., LINTAULT, L., PATEL, O., ENEMAN, J., CROCKER, A., WHITE, J., TESSITORE, J., et al., (2009). Molecular signatures suggest a major role for stromal cells in development of invasive breast cancer. Breast Cancer Res Treat 114: 47-62.

CHENG, J.D., and WEINER, L.M. (2003). Tumors and their microenvironments: tilling the soil. Commentary re: A. M. Scott et al., A Phase I dose-escalation study of sibrotuzumab in patients with advanced or metastatic fibroblast activation protein-positive cancer. Clin. Cancer Res., 9: 1639-1647, 2003. Clin Cancer Res 9: 1590-1595.

CHENG, N., BHOWMICK, N.A., CHYTIL, A., GORKSA, A.E., BROWN, K.A., MURAOKA, R., ARTEAGA, C.L., NEILSON, E.G., HAYWARD, S.W., and MOSES, H.L. (2005). Loss of TGF-beta type II receptor in fibroblasts promotes mammary carcinoma growth and invasion through upregulation of TGF-alpha-, MSP- and HGF-mediated signaling networks. Oncogene 24: 5053-5068.

CULLY, M., YOU, H., LEVINE, A.J., and MAK, T.W. (2006). Beyond PTEN mutations: the PI3K pathway as an integrator of multiple inputs during tumorigenesis. Nat Rev Cancer 6: 184-192.

DE KRUIJF, E.M., VAN NES, J.G., VAN DE VELDE, C.J., PUTTER, H., SMIT, V.T., LIEFERS, G.J., KUPPEN, P.J., TOLLENAAR, R.A., and MESKER, W.E. (2011). Tumor-stroma ratio in the primary tumor is a prognostic factor in early breast cancer patients, especially in triple-negative carcinoma patients. Breast Cancer Res Treat 125: 687-696.

DE WEVER, O., DEMETTER, P., MAREEL, M., and BRACKE, M. (2008). Stroma myofibroblasts are drivers of invasive cancer growth. Int J Cancer 123:2229-2238.

DVORAK, H.F. (1986). Tumors: wounds that do not heal. Similarities between tumor stroma generation and wound healing. N Engl J Med 315: 1650-1659.

EL-HAIBI, C.P., and KARNOUB, A.E. (2010). Mesenchymal stem cells in the pathogenesis and therapy of breast cancer. J Mammary Gland Biol Neoplasia 15: 399-409.

ENG, C., LEONE, G., ORLOFF, M.S., and OSTROWSKI, M.C. (2009). Genomic alterations in tumor stroma. Cancer Res 69: 6759-6764.

ENGELMAN, J.A., LEE, R.J., KARNEZIS, A., BEARSS, D.J., WEBSTER, M., SIEGEL, P., MULLER, W.J., WINDLE, J.J., PESTELL, R.G., and LISANTI, M.P. (1998) Reciprocal regulation of neu tyrosine kinase activity and caveolin-1 protein expression in vitro and in vivo. Implications for human breast cancer. J Biol Chem 273: 20448-20455

FARMER, P., BONNEFOI, H., ANDERLE, P., CAMERON, D., WIRAPATI, P., BECETTE V., ANDRE, S., PICCART, M., CAMPONE, M., BRAIN, E., et al., (2009). A stromarelated gene signature predicts resistance to neoadjuvant chemotherapy in breast cancer. Nat Med 15: 68-74.

FIEGL, H., MILLINGER, S., GOEBEL, G., MULLER-HOLZNER, E., MARTH, C., LAIRD, P.W., and WIDSCHWENDTER, M. (2006). Breast cancer DNAmethylation profiles in cancer cells and tumor stroma: association with HER-2/neu status in primary breast cancer. Cancer Res 66: 29-33.

FINAK, G., BERTOS, N., PEPIN, F., SADEKOVA, S., SOULEIMANOVA, M., ZHAO, H., CHEN, H., OMEROGLU, G., METERISSIAN, S., OMEROGLU, A., et al., (2008). Stromal gene expression predicts clinical outcome in breast cancer. Nat Med 14: 518-527.

FRIEDL,A. (2009). Proteoglycans: master modulators of paracrine fibroblast-carcinoma cell interactions. Semin Cell Dev Biol 21: 66-71.

FUKINO, K., SHEN, L., PATOCS, A., MUTTER, G.L., and ENG, C. (2007). Genomic instability within tumor stroma and clinicopathological characteristics of sporadic primary invasive breast carcinoma. JAMA 297: 2103-2111.

GABBIANI, G., RYAN, G.B., and MAJNE, G. (1971). Presence of modified fibroblasts in granulation tissue and their possible role in wound contraction. Experientia 27: $549-550$.

HAGGIE, J.A., SELLWOOD, R.A., HOWELL, A., BIRCH, J.M., and SCHOR, S.L. (1987). Fibroblasts from relatives of patients with hereditary breast cancer show fetal-like behaviour in vitro. Lancet 1: 1455-1457.

HANNAN, M.A., SIDDIQUI, Y., ROSTOM, A., AL-AHDAL, M.N., CHAUDHARY, M.A., and KUNHI, M. (2001). Evidence of DNA repair/processing defects in cultured skin fibroblasts from breast cancer patients. Cancer Res 61: 3627-3631.

HASEBE, T., TAMURA, N., OKADA, N., HOJO, T., AKASHI-TANAKA, S., SHIMIZU, C., TSUDA, H., SHIBATA, T., SASAJIMA, Y., IWASAKI, M., et al., (2010). p53 expression in tumor-stromal fibroblasts is closely associated with the nodal metastasis and outcome of patients with invasive ductal carcinoma who received neoadjuvant therapy. Hum Pathol 41: 262-270. 
HAWSAWI, N.M., GHEBEH, H., HENDRAYANI, S.F., TULBAH, A., AL-EID, M., ALTWEIGERI, T., AJARIM, D., ALAIYA, A., DERMIME, S., and ABOUSSEKHRA, A. (2008). Breast carcinoma-associated fibroblasts and their counterparts display neoplastic-specific changes. Cancer Res 68: 2717-2725.

HU, M., PELUFFO, G., CHEN, H., GELMAN, R., SCHNITT, S., and POLYAK, K. (2009). Role of COX-2 in epithelial-stromal cell interactions and progression of ductal carcinoma in situ of the breast. Proc Natl Acad Sci USA 106: 3372-3377.

HU, M., and POLYAK, K. (2008). Molecular characterisation of the tumour microenvironment in breast cancer. Eur J Cancer 44: 2760-2765.

HU, M., YAO, J., CAI, L., BACHMAN, K.E., VAN DEN BRULE, F., VELCULESCU, V., and POLYAK, K. (2005). Distinct epigenetic changes in the stromal cells of breast cancers. Nat Genet 37: 899-905.

HUANG, M., LI, Y., ZHANG, H., and NAN, F. (2010). Breast cancer stromal fibroblasts promote the generation of CD44+CD24- cells through SDF-1/CXCR4 interaction. J. Exp. Clin. Cancer Res. 29: 80.

JEMAL, A., BRAY, F., CENTER, M.M., FERLAY, J., WARD, E., and FORMAN, D. (2011). Global cancer statistics. Ca Cancer J Clin 61: 69-90.

JEON, E.S., MOON, H.J., LEE, M.J., SONG, H.Y., KIM, Y.M., CHO, M., SUH, D.S., YOON, M.S., CHANG, C.L., JUNG, J.S., et al., (2008). Cancer-derived lysophosphatidic acid stimulates differentiation of human mesenchymal stem cells to myofibroblast-like cells. Stem Cells 26: 789-797.

KALLURI, R., and WEINBERG, R.A. (2009). The basics of epithelial-mesenchymal transition. J Clin Invest 119: 1420-1428.

KALLURI, R., and ZEISBERG, M. (2006). Fibroblasts in cancer. Nat Rev Cancer 6: 392-401.

KESSENBROCK, K., PLAKS, V., and WERB, Z. (2010). Matrix metalloproteinases: regulators of the tumor microenvironment. Cell 141: 52-67.

KHWAJA, F.W., SVOBODA, P., REED, M., POHL, J., PYRZYNSKA, B., and VAN MEIR, E.G. (2006). Proteomic identification of the wt-p53-regulated tumor cell secretome. Oncogene 25: 7650-7661.

KIARIS, H., CHATZISTAMOU, I., TRIMIS, G., FRANGOU-PLEMMENOU, M., PAFITIKONDI, A., and KALOFOUTIS, A. (2005). Evidence for nonautonomous effect of p53 tumor suppressor in carcinogenesis. Cancer Res 65: 1627-1630.

KIM, J.B., STEIN, R., and O'HARE, M.J. (2005). Tumour-stromal interactions in breast cancer: the role of stroma in tumourigenesis. Tumour Biol 26: 173-185.

KOBAYASHI, T., TSUDA, H., MORIYA, T., YAMASAKI, T., KIKUCHI, R., UEDA, S., OMATA, J., YAMAMOTO, J., and MATSUBARA, O. (2009). Expression pattern of stromal cell-derived factor-1 chemokine in invasive breast cancer is correlated with estrogen receptor status and patient prognosis. Breast Cancer Res Treat 123: 733-745

KOJIMA, Y., ACAR, A., EATON, E.N., MELLODY, K.T., SCHEEL, C., BEN-PORATH, I., ONDER, T.T., WANG, Z.C., RICHARDSON, A.L., WEINBERG, R.A., et al., (2010). Autocrine TGF-beta and stromal cell-derived factor-1 (SDF-1) signaling drives the evolution of tumor-promoting mammary stromal myofibroblasts. Proc Natl Acad Sci USA 107: 20009-20014.

KOMAROVA, E.A., DIATCHENKO, L., ROKHLIN, O.W., HILL, J.E., WANG, Z.J., KRIVOKRYSENKO, V.I., FEINSTEIN, E., and GUDKOV, A.V. (1998). Stressinduced secretion of growth inhibitors: a novel tumor suppressor function of p53. Oncogene 17: 1089-1096.

KUPERWASSER, C., CHAVARRIA, T., WU, M., MAGRANE, G., GRAY, J.W., CAREY, L., RICHARDSON, A., and WEINBERG, R.A. (2004). Reconstruction of functionally normal and malignant human breast tissues in mice. Proc Natl Acad Sci USA 101: 4966-4971.

KUROSE, K., GILLEY, K., MATSUMOTO, S., WATSON, P.H., ZHOU, X.P., and ENG, C. (2002). Frequent somatic mutations in PTEN and TP53 are mutually exclusive in the stroma of breast carcinomas. Nat Genet 32: 355-357.

LEE, S.W., REIMER, C.L., OH, P., CAMPBELL, D.B., and SCHNITZER, J.E. (1998). Tumor cell growth inhibition by caveolin re-expression in human breast cancer cells. Oncogene 16: 1391-1397.

LIN, H.J., ZUO, T., CHAO, J.R., PENG, Z., ASAMOTO, L.K., YAMASHITA, S.S., and HUANG, T.H. (2009). Seed in soil, with an epigenetic view. Biochim Biophys Acta 1790: 920-924.

LIN, H.J., ZUO, T., LIN, C.H., KUO, C.T., LIYANARACHCHI, S., SUN, S., SHEN, R., DEATHERAGE, D.E., POTTER, D., ASAMOTO, L., et al., (2008). Breast cancerassociated fibroblasts confer AKT1-mediated epigenetic silencing of Cystatin M in epithelial cells. Cancer Res 68: 10257-10266.
LYNCH, C.C., and MATRISIAN, L.M. (2002). Matrix metalloproteinases in tumor-host cell communication. Differentiation 70: 561-573.

MA, X.J., DAHIYA, S., RICHARDSON, E., ERLANDER, M., and SGROI, D.C. (2009). Gene expression profiling of the tumor microenvironment during breast cancer progression. Breast Cancer Res 11: R7.

MAEDA, T., DESOUKY, J., and FRIEDL, A. (2006). Syndecan-1 expression by stromal fibroblasts promotes breast carcinoma growth in vivo and stimulates tumor angiogenesis. Oncogene 25: 1408-1412.

MAKRETSOV, N.A., HAYES, M., CARTER, B.A., DABIRI, S., GILKS, C.B., and HUNTSMAN, D.G. (2007). Stromal CD10 expression in invasive breast carcinoma correlates with poor prognosis, estrogen receptor negativity, and high grade. Mod Pathol 20: 84-89.

MASSAGUE, J. (2008). TGFbeta in Cancer. Cell 134: 215-230.

MASSON, R., LEFEBVRE, O., NOEL, A., FAHIME, M.E., CHENARD, M.P., WENDLING C., KEBERS, F., LEMEUR, M., DIERICH, A., FOIDART, J.M., et al., (1998). In vivo evidence that the stromelysin-3 metalloproteinase contributes in a paracrine manner to epithelial cell malignancy. J Cell Biol 140: 1535-1541.

MATSUMOTO, K., and NAKAMURA, T. (2006). Hepatocyte growth factor and the Met system as a mediator of tumor-stromal interactions. Int J Cancer 119: 477-483.

MISHRA, P.J., MISHRA, P.J., HUMENIUK, R., MEDINA, D.J., ALEXE, G., MESIROV, J.P., GANESAN, S., GLOD, J.W., and BANERJEE, D. (2008). Carcinoma-associated fibroblast-like differentiation of human mesenchymal stem cells. Cancer Res 68: 4331-4339.

MOINFAR, F., MAN, Y.G., ARNOULD, L., BRATTHAUER, G.L., RATSCHEK, M., and TAVASSOLI, F.A. (2000). Concurrent and independent genetic alterations in the stromal and epithelial cells of mammary carcinoma: implications for tumorigenesis. Cancer Res 60: 2562-2566.

MORI, L., BELLINI, A., STACEY, M.A., SCHMIDT, M., and MATTOLI, S. (2005). Fibrocytes contribute to the myofibroblast population in wounded skin and originate from the bone marrow. Exp Cell Res 304: 81-90.

MOSKOVITS, N., KALINKOVICH, A., BAR, J., LAPIDOT, T., and OREN, M. (2006) p53 Attenuates cancer cell migration and invasion through repression of SDF-1/ CXCL12 expression in stromal fibroblasts. Cancer Res 66: 10671-10676.

NABESHIMA, K., INOUE, T., SHIMAO, Y., and SAMESHIMA, T. (2002). Matrix metalloproteinases in tumor invasion: role for cell migration. Pathol Int 52: 255-264.

NOEL, A., DE PAUW-GILLET, M.C., PURNELL, G., NUSGENS, B., LAPIERE, C.M., and FOIDART, J.M. (1993). Enhancement of tumorigenicity of human breast adenocarcinoma cells in nude mice by matrigel and fibroblasts. Br J Cancer 68: 909-915.

ORIMO, A., GUPTA, P.B., SGROI, D.C., ARENZANA-SEISDEDOS, F., DELAUNAY, T., NAEEM, R., CAREY, V.J., RICHARDSON, A.L., and WEINBERG, R.A. (2005). Stromal fibroblasts present in invasive human breast carcinomas promote tumor growth and angiogenesis through elevated SDF-1/CXCL12 secretion. Cell 121 335-348.

PAULSSON, J., SJOBLOM, T., MICKE, P., PONTEN, F., LANDBERG, G., HELDIN, C.H., BERGH, J., BRENNAN, D.J., JIRSTROM, K., and OSTMAN, A. (2009). Prognostic significance of stromal platelet-derived growth factor beta-receptor expression in human breast cancer. Am J Pathol 175: 334-341.

PIETRAS, K., and OSTMAN, A. (2010). Hallmarks of cancer: interactions with the tumor stroma. Exp Cell Res 316: 1324-1331.

PINTO, M.P., BADTKE, M.M., DUDEVOIR, M.L., HARRELL, J.C., JACOBSEN, B.M., and HORWITZ, K.B. (2010). Vascular endothelial growth factor secreted by activated stroma enhances angiogenesis and hormone-independent growth of estrogen receptor-positive breast cancer. Cancer 70: 2655-2664.

POLYAK, K., and KALLURI, R. (2010). The Role of the Microenvironment in Mammary Gland Development and Cancer. Cold Spring Harb Perspect Biol 2010: 30.

POLYAK, K., and WEINBERG, R.A. (2009). Transitions between epithelial and mesenchymal states: acquisition of malignant and stem cell traits. Nat Rev Cancer 9: 265-273.

POTENTA, S., ZEISBERG, E., and KALLURI, R. (2008). The role of endothelialto-mesenchymal transition in cancer progression. Br J Cancer 99: 1375-1379.

RIVENBARK, A.G., LIVASY, C.A., BOYD, C.E., KEPPLER, D., and COLEMAN, W.B. (2007). Methylation-dependent silencing of CST6 in primary human breast tumors and metastatic lesions. Exp Mol Pathol 83: 188-197.

RONNOV-JESSEN, L., PETERSEN, O.W., KOTELIANSKY, V.E., and BISSELL, M.J. (1995). The origin of the myofibroblasts in breast cancer. Recapitulation of tumor environment in culture unravels diversity and implicates converted fibroblasts and 
recruited smooth muscle cells. J Clin Invest 95: 859-873.

ROZENCHAN, P.B., CARRARO, D.M., BRENTANI, H., DE CARVALHO MOTA, L.D., BASTOS, E.P., E FERREIRA, E.N., TORRES, C.H., KATAYAMA, M.L., ROELA R.A., LYRA, E.C., et al., (2009). Reciprocal changes in gene expression profiles of cocultured breast epithelial cells and primary fibroblasts. Int $J$ Cancer 125 : 2767-2777.

SADLONOVA, A., BOWE, D.B., NOVAK, Z., MUKHERJEE, S., DUNCAN, V.E., PAGE, G.P., and FROST, A.R. (2009). Identification of molecular distinctions between normal breast-associated fibroblasts and breast cancer-associated fibroblasts. Cancer Microenviron 2: 9-21.

SAPPINO, A.P., SCHURCH, W., and GABBIANI, G. (1990). Differentiation repertoire of fibroblastic cells: expression of cytoskeletal proteins as marker of phenotypic modulations. Lab Invest 63: 144-161.

SAPPINO, A.P., SKALLI, O., JACKSON, B., SCHURCH, W., and GABBIANI, G. (1988). Smooth-muscle differentiation in stromal cells of malignant and non-malignant breast tissues. Int J Cancer 41: 707-712.

SCHOR, S.L., and SCHOR, A.M. (2001). Phenotypic and genetic alterations in mammary stroma: implications for tumour progression. Breast Cancer Res 3: 373-379.

SCHOR, S.L., SCHOR, A.M., DURNING, P., and RUSHTON, G. (1985). Skin fibroblasts obtained from cancer patients display foetal-like migratory behaviour on collagen gels. J Cell Sci 73: 235-244.

SHEKHAR, M.P., WERDELL, J., SANTNER, S.J., PAULEY, R.J., and TAIT, L. (2001). Breast stroma plays a dominant regulatory role in breast epithelial growth and differentiation: implications for tumor development and progression. Cancer Res 61: $1320-1326$

SLOAN, E.K., CIOCCA, D.R., POULIOT, N., NATOLI, A., RESTALL, C., HENDERSON, M.A., FANELLI, M.A., CUELLO-CARRION, F.D., GAGO, F.E., and ANDERSON, R.L. (2009). Stromal cell expression of caveolin-1 predicts outcome in breast cancer. Am J Pathol 174: 2035-2043.

SOTGIA, F., DEL GALDO, F., CASIMIRO, M.C., BONUCCELLI, G., MERCIER, I., WHITAKER-MENEZES, D., DAUMER, K.M., ZHOU, J., WANG, C., KATIYAR, S., et al., (2009). Caveolin-1-/-null mammary stromal fibroblasts share characteristics with human breast cancer-associated fibroblasts. Am J Pathol 174: 746-761.

SPAETH, E.L., DEMBINSKI, J.L., SASSER, A.K., WATSON, K., KLOPP, A., HALL, B., ANDREEFF, M., and MARINI, F. (2009). Mesenchymal stem cell transition to tumor-associated fibroblasts contributes to fibrovascular network expansion and tumor progression. PLoS One 4: e4992.

STUELTEN, C.H., DACOSTABYFIELD, S., ARANY, P.R., KARPOVA, T.S., STETLERSTEVENSON, W.G., and ROBERTS, A.B. (2005). Breast cancer cells induce stromal fibroblasts to express MMP-9 via secretion of TNF-alpha and TGF-beta. J Cell Sci 118: 2143-2153.

SU, G., BLAINE, S.A., QIAO, D., and FRIEDL, A. (2007). Shedding of syndecan-1 by stromal fibroblasts stimulates human breast cancer cell proliferation via FGF2 activation. J Biol Chem 282: 14906-14915.

TARIN, D. (1969). Fine structure of murine mammary tumours: the relationship between epithelium and connective tissue in neoplasms induced by various agents. Br J Cancer 23: 417-425.

TEICHER, B.A., and FRICKER, S.P. (2010). CXCL12 (SDF-1)/CXCR4 pathway in cancer. Clin Cancer Res 16: 2927-2931.

TOMASEK, J.J., GABBIANI, G., HINZ, B., CHAPONNIER, C., and BROWN, R.A. (2002). Myofibroblasts and mechano-regulation of connective tissue remodelling.
Nat Rev Mol Cell Biol 3: 349-363.

TRIMBOLI, A.J., CANTEMIR-STONE, C.Z., LI, F., WALLACE, J.A., MERCHANT, A., CREASAP, N., THOMPSON, J.C., CASERTA, E., WANG, H., CHONG, J.L., et al., (2009). Pten in stromal fibroblasts suppresses mammary epithelial tumours. Nature 461: 1084-1091.

TRIMIS, G., CHATZISTAMOU, I., POLITI, K., KIARIS, H., and PAPAVASSILIOU, A.G. (2008). Expression of p21waf1/Cip1 in stromal fibroblasts of primary breast tumors. Hum Mol Genet 17: 3596-3600.

TRIMMER, C., SOTGIA, F., WHITAKER-MENEZES, D., BALLIET, R.M., EATON, G., MARTINEZ-OUTSCHOORN, U.E., PAVLIDES, S., HOWELL, A., IOZZO, R.V., PESTELL, R.G., et al., (2011). Caveolin-1 and mitochondrial SOD2 (MnSOD) function as tumor suppressors in the stromal microenvironment: a new genetically tractable model for human cancer associated fibroblasts. Cancer 11: 383-394.

TYAN, S.W., KUO, W.H., HUANG, C.K., PAN, C.C., SHEW, J.Y., CHANG, K.J., LEE, E.Y., and LEE, W.H. (2011). Breast cancer cells induce cancer-associated fibroblasts to secrete hepatocyte growth factor to enhance breast tumorigenesis. PLoS one 6: e15313.

VAUGHAN, M.B., HOWARD, E.W., and TOMASEK, J.J. (2000). Transforming growth factor-beta1 promotes the morphological and functional differentiation of the myofibroblast. Exp Cell Res 257: 180-189.

WANG, T.N., ALBO, D., and TUSZYNSKI, G.P. (2002). Fibroblasts promote breast cancer cell invasion by upregulating tumor matrix metalloproteinase-9 production. Surgery 132: 220-225.

WEBER, F., SHEN, L., FUKINO, K., PATOCS, A., MUTTER, G.L., CALDES, T., and ENG, C. (2006). Total-genome analysis of BRCA1/2-related invasive carcinomas of the breast identifies tumor stroma as potential landscaper for neoplastic initiation. Am J Hum Genet 78: 961-972.

WERNERT, N., LOCHERBACH, C., WELLMANN, A., BEHRENS, P., and HUGEL, A (2001). Presence of genetic alterations in microdissected stroma of human colon and breast cancers. Anticancer Res 21: 2259-2264.

WILLIAMS, T.M., LEE, H., CHEUNG, M.W., COHEN, A.W., RAZANI, B., IYENGAR P., SCHERER, P.E., PESTELL, R.G., and LISANTI, M.P. (2004). Combined loss of INK4a and caveolin-1 synergistically enhances cell proliferation and oncogeneinduced tumorigenesis: role of INK4a/CAV-1 in mammary epithelial cell hyperplasia J Biol Chem 279: 24745-24756.

WITKIEWICZ, A.K., CASIMIRO, M.C., DASGUPTA, A., MERCIER, I., WANG, C. BONUCCELLI, G., JASMIN, J.F., FRANK, P.G., PESTELL, R.G., KLEER, C.G., et al., (2009). Towards a new "stromal-based" classification system for human breast cancer prognosis and therapy. Cell Cycle 8: 1654-1658.

WU, M., JUNG, L., COOPER, A.B., FLEET, C., CHEN, L., BREAULT, L., CLARK, K. CAI, Z., VINCENT, S., BOTTEGA, S., et al., (2009). Dissecting genetic requirements of human breast tumorigenesis in a tissue transgenic model of human breast cancer in mice. Proc Natl Acad Sci USA 106: 7022-7027.

YAMASHITA, M., OGAWA, T., ZHANG, X., HANAMURA, N., KASHIKURA, Y., TAKAMURA, M., YONEDA, M., and SHIRAISHI, T. (2010). Role of stromal myofibroblasts in invasive breast cancer: stromal expression of alpha-smooth muscle actin correlates with worse clinical outcome. Breast Cancer 2010: 27.

ZEISBERG, E.M., POTENTA, S., XIE, L., ZEISBERG, M., and KALLURI, R. (2007) Discovery of endothelial to mesenchymal transition as a source for carcinomaassociated fibroblasts. Cancer Res 67: 10123-10128. 


\section{Further Related Reading, published previously in the Int. J. Dev. Biol.}

The role of pericytes in angiogenesis

Domenico Ribatti, Beatrice Nico and Enrico Crivellato Int. J. Dev. Biol. (2011) 55: 261-268

Casein kinase I epsilon somatic mutations found in breast cancer cause overgrowth in Drosophila Tomas Dolezal, Katerina Kucerova, Jana Neuhold and Peter J. Bryant Int. J. Dev. Biol. (2010) 54: 1419-1424

Role of fetal membranes in signaling of fetal maturation and parturition Leslie Myatt and Kang Sun

Int. J. Dev. Biol. (2010) 54: 545-553

The contribution of Roberto Montesano to the study of interactions between epithelial sheets and the surrounding extracellular matrix Domenico Ribatti

Int. J. Dev. Biol. (2010) 54: 1-6

Epithelial-Mesenchymal Transitions in development and disease: old views and new perspectives

M. Angela Nieto

Int. J. Dev. Biol. (2009) 53: 1541-1547

5 yr ISI Impact Factor $(2010)=2.961$

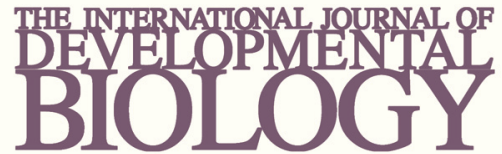

Volume 54 Nos. 6/7

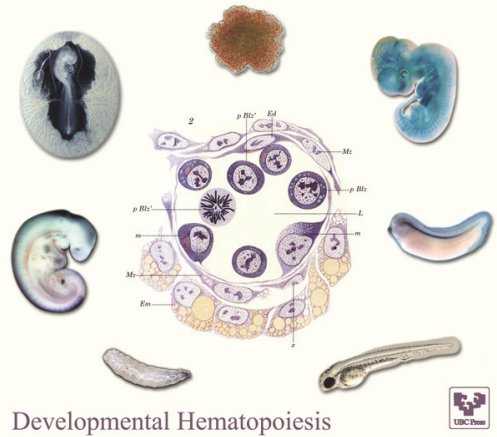

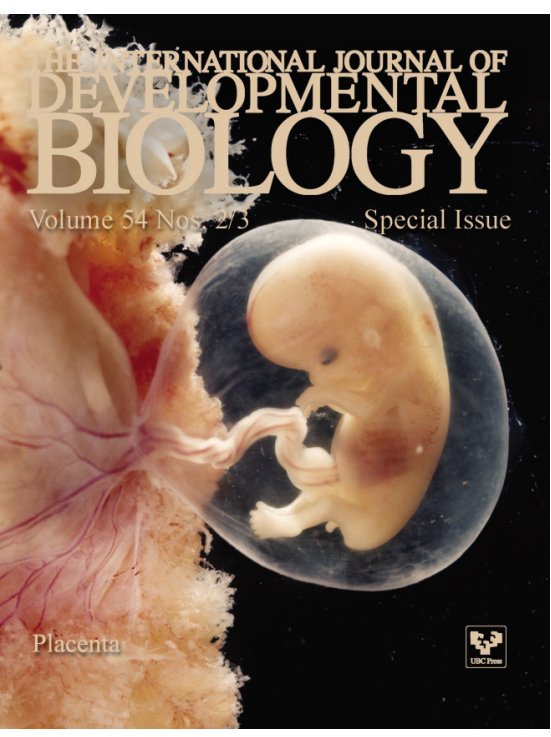

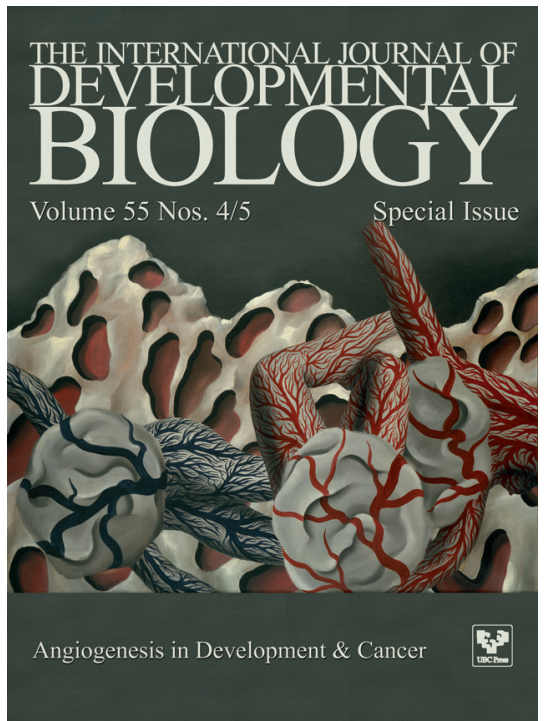

